症例報告

関節リウマチに伴う急速進行性間質性肺炎及び多発肺囊胞の治療中に縦隔気腫を合併し, tacrolimus が有効であった 1 例

\author{
越智小枝, 窪田哲朗, 杉原毅彦, 小川純 \\ 駒野有希子，野々村美紀，宮 坂 信 之
}

\title{
A case report of rheumatoid arthritis complicated with rapidly progressive interstitial pneumonia, multiple bullae and pneumomediastinum, which was successfully treated with tacrolimus
}

\author{
Sae Ochi, Tetsuo Kubota, Takahiko Sugihara, Jun Ogawa, \\ Yukiko Komano, Yoshinori NonOMURA and Nobuyuki MiYASAKA \\ Department of Medicine and Rheumatology, Tokyo Medical and Dental University
}

(Received October 30, 2007)

\begin{abstract}
summary
A 64-year-old woman had been treated with prednisolone (PSL) for interstitial pneumonia (IP) of unknown origin since 1988. The IP progressed gradually, however, and home oxygen therapy was instituted in 1993. In 2002, persistent arthritis of the hands appeared and diagnosis of rheumatoid arthritis (RA) was finally established based on radiological and pathological findings. Salazosulfapyridine was given with only partial effect. On October 2002, she was hospitalized because of back pain followed by dyspnea. Chest X-ray revealed multiple giant bullae on bilateral upper lung fields, accompanied by deterioration of IP. Methyl-prednisolone pulse therapy followed by $30 \mathrm{mg} / \mathrm{day}$ of PSL was instituted and the bullae were diminished with gradual improvement of IP and synovitis. On the 55th hospital day, she complained of chest oppression, and chest X-ray revealed a complication of pneumomediastinum. Since IP was still active and serum KL-6 remained high, $3 \mathrm{mg} /$ day of tacrolimus was added to control IP further and to reduce the dosage of PSL which was recognized as one of the aggravation factors of pneumomediastinum. As a result, pneumomediastinum disappeared gradually along with amelioration of IP. PSL was successfully tapered to $15 \mathrm{mg} /$ day by the 87 th hospital day and the patient was discharged. Although the efficacy of tacrolimus on IP complicated with polymyositis / dermatomyositis and other autoimmune diseases has been reported, this case first suggests its efficacy on IP associated with RA.
\end{abstract}

Key words - rheumatoid arthritis; interstitial pneumonia; multiple bullae; pneumomediastinum; tacrolimus

抄録

症例は 64 歳, 女性. 1988 年, 労作時呼吸困難が出現し, 間質性肺炎（IP）と診断された. Prednisolone (PSL) $40 \mathrm{mg} /$ 日による治療が開始され，1991 年からは $5 \mathrm{mg} /$ 日の維持量が投与されていたが IP は緩徐に進行し，1993 年 に在宅酸素療法導入となった。 2002 年 3 月より関節炎が持続し, X 線所見, 病理所見から関節リウマチの診断が 確定し, salazosulfapyridine 投与が開始された。同年 10 月, 突然の背部痛の後呼吸困難が生じ, 胸部 X 線像およ び CT 像にて IP の増悪と多発肺囊胞を認めた. Methyl-prednisoloneパルス療法を行い，その後 PSL $30 \mathrm{mg} /$ 日を 経口投与したところ, 関節炎は改善し肺嚢胞も縮小したが，第 55 病日には前胸部の絞扼感とともに縦隔気腫が出 現した. IP が遷延し，血清 KL-6 值が依然として高值であったため, tacrolimus $3 \mathrm{mg} /$ 日を併用しながら PSLを減 量した. その後縦隔気腫の消失と IP 及び関節炎の改善を認め, 第 87 病日退院となった. 近年皮膚筋炎/多発性筋 炎などに合併した IP に対する tacrolimus の有効性が報告されているが，本例は tacrolimus が関節リウマチに合併 する IP に対しても有効であることを示唆する症例である.

I. はじめに

関節リウマチ（RA）に合併する肺病変には，胸
膜炎, 間質性肺炎 (IP), 閉塞性細気管支炎（bronchiolitis obliterans, BO), 肺内リウマトイド結節な ぞ多彩な病態が知られている. 中でも進行性の IP は生命予後を左右する重要な病態であるが，RAに 合併する IP は薬剤や感染などの因子の除外が困難 
なことが多く，治療法も確立していない1)，入院を 必要とした RA に伴うIPに打いては，その80\%が 治療抵抗性であり, 平均生存期間が 3.5 年, 5 年生 存率が 39\%であったという報告もあり，重症の IP は RAの予後を大きく左右する因子である2).

近年 RA に対して，マクロライド系免疫抑制薬で ある tacrolimus の有効性が証明され3)，2005 年に世 界に先駆けて本邦において初めて保険適用が認めら れた．他の自己免疫病態に対する tacrolimus の効 果に関しては，大規模試験による検討は行われてい ないものの，多発性筋炎 $(\mathrm{PM}) /$ 皮虐筋炎 $(\mathrm{DM})$ に合併する IP $4,5,6)$ をはじめ, 膠原病の種々の難治 性病態に対する有効性を報告した論文が散見され $3^{6-9)}$. 今回我々は, RA の加療中に多発巨大肺囊 胞を伴う急速進行性の IP と綐隔気腫を併発し, IP 及び関節炎のコントロールと副腎皮質ステロイド薬 の減量に tacrolimus が有効であった 1 例を経験し たので報告する.

\section{II. 症例}

症 例 : 64 歳, 女性

主 訴: 背部痛, 呼吸困難

現病歴：1988 年労作時呼吸困難を生じ, 近医を 受診．胸部 X 線像にて IP を認めたため当院に紹介 受診となった. 1989 年 7 月に労作時呼吸困難の増 悪のため精査目的で入院し, 経気管支肺生検にて non-specific IP（NSIP）の所見を認めた. Prednisolone (PSL) $40 \mathrm{mg} /$ 日の経口投与を受けて症状が改 善し，退院となった。な打基礎疾患として，手のこ わばり, レイノー現象, 抗核抗体陽性（80 倍, speckled pattern), 抗 Scl-70 抗体陽性（4 倍）など
より強皮症が疑われ，皮膚硬化は明らかではなかっ たが D-penicillamine (D-PC) $100 \mathrm{mg} /$ 日の併用投与 も開始された。その後，1991 年までに PSL は $5 \mathrm{mg}$ /日まで漸減していたが IP は緩徐に進行し，1993 年より在宅酸素療法を導入していた。 2002 年に左 第 II 指 MCP 関節が腫脹し, 手指の X 線像にて骨 びらんを認めた。単関節炎であり, 副腎皮質ステロ イド薬内服中にもかかわらずッベルクリン反応が陽 性であったため, 結核性関節炎なども否定するため に滑膜切除・生検を実施したところ, 病理所見はリ ウマトイド結節であった。このため IP 先行の RA と診断し，D-PCは中止して salazosulfapyridine $1,000 \mathrm{mg} /$ 日投与に变更したが，関節炎は徐々に手 指, 足関節などに進展した。 また乾性咳嗽, 労作時 の息切れも続いており, 同年 5 月頃より血清 KL-6 值は $1,000 \mathrm{U} / \mathrm{mL}$ 以上の高值が続いていた. 同年 10 月 11 日, 突然左側背部痛を自覚したが数時間で 消失した。10月 20 日より労作時呼吸困難, 乾性咳 嗽の増悪を認めたため, 11 月 1 日当院救急外来を 受診. 低酸素血症, 胸部 X 線像にて多発肺囊胞を 認め, 緊急入院となった. 経過中発熱は認めなかっ た。

生活歴：泪煙歴なし，粉塵吸入歴なし

家族歴・既往歴 : 特記すべきことなし

入院時現症：血圧 138/88 mmHg, 脈拍 $108 /$ 分. 整, 呼吸数 $40 /$ 分, 体温 $36.7^{\circ} \mathrm{C}$, 左上肺野で呼吸音 は減弱し, 両側下肺野に fine crackles を聴取した。 右足関節と左第 II 指 MCP 関節に圧痛・腫脹を認め た (圧痛関節数 $: 2$, 腫脹関節数 $: 2$ ). 入院時検査 所見を表 1 に示す. 白血球増多, CRP 高值, リウ マトイド因子弱陽性を認め, また血清 KL-6 值

表 1 入院時検査所見

\begin{tabular}{|c|c|c|c|c|c|}
\hline 赤沈 & & 生化学 & & $\beta-\mathrm{D}$ グルカン & 陰性 \\
\hline 1 時間值 & $99 \mathrm{~mm}$ & $\mathrm{TP}$ & $7.5 \mathrm{~g} / \mathrm{dL}$ & CMV アンチゲネミア & 陰性 \\
\hline 血算 & & Alb & $3.8 \mathrm{~g} / \mathrm{dL}$ & 血液ガス $\left(\mathrm{O}_{2} 2 \mathrm{~L} / \mathrm{min}\right)$ & \\
\hline WBC & $13400 / \mu \mathrm{L}$ & BUN & $12.1 \mathrm{mg} / \mathrm{dL}$ & $\mathrm{pH}$ & 7.407 \\
\hline Stab & $0 \%$ & Cre & $0.6 \mathrm{mg} / \mathrm{dL}$ & $\mathrm{PaO}_{2}$ & 0 Torr \\
\hline Seg & $79 \%$ & AST & $20 \mathrm{U} / \mathrm{L}$ & $\mathrm{PaCO}_{2}$ & 5 Torr \\
\hline Lym & $13 \%$ & ALT & $71 \mathrm{U} / \mathrm{L}$ & $\mathrm{SaO}_{2}$ & $89.0 \%$ \\
\hline Mo & $4 \%$ & $\mathrm{LDH}$ & $140 \mathrm{U} / \mathrm{L}$ & $\mathrm{HCO}_{3}^{-}$ & $\mathrm{mol} / \mathrm{L}$ \\
\hline Eo & $1 \%$ & Glu & $104 \mathrm{mg} / \mathrm{dL}$ & $\mathrm{BE}$ & -0.2 \\
\hline $\mathrm{Ba}$ & $3 \%$ & 血清 & & 喀痰培養 & \\
\hline $\mathrm{RBC}$ & 431 万 $/ \mu \mathrm{L}$ & $\mathrm{CRP}$ & $6.9 \mathrm{mg} / \mathrm{dL}$ & 一般細菌·抗酸菌 & 陰性 \\
\hline $\mathrm{Hb}$ & $14.0 \mathrm{~g} / \mathrm{dL}$ & RAPA & 40 倍 & 結核菌 PCR & 陰性 \\
\hline $\mathrm{Ht}$ & $43.6 \%$ & $\mathrm{KL}-6$ & $2530 \mathrm{U} / \mathrm{mL}$ & & \\
\hline Plt & 35.6 万 $/ \mu \mathrm{L}$ & & & & \\
\hline
\end{tabular}


$(2,530 \mathrm{U} / \mathrm{mL})$ は，同年 10 月 11 日の值 $(1,380 \mathrm{U} /$ $\mathrm{mL})$ に比べて上昇していた． $\mathrm{O}_{2} 2 \mathrm{~L}$ 経鼻投与下に て $\mathrm{PaO}_{2} 54$ Torr と著明な低酸素血症を認めた。 $\beta-$ D グルカン, サイトメガロアンチゲネミアは陰 性, 喀痰の一般細菌, 抗酸菌培養および結核菌 PCR も陰性であった。

入院時胸部 X 線像を図 $1 \mathrm{a}$ に示す。両側全肺野に 網状影及びスリガラス影を認め, 下肺野は蜂窩状で あった，左肺野に巨大な肺囊胞が多発していた。胸 部 CT 像（図 1b）では右肺にも囊胞を認めたほか， 両側中〜下肺野にスリガラス影を認め，同年 6 月に 比べて病変部が拡大していた。肺囊胞の壁肥厚や造 影効果はみられなかった。 また，手指の X 線像に
て左手根骨と第II指 MCP 関節にびらん性変化を認 めた.

入院後経過（図 2)：胸部 X 線像にてスリガラス 影の拡大を認め，さらに血清 KL-6 值が上昇してい たことより，IP の増悪に伴って細気管支の狭窄が 起こり, チェックバルブ機構により進行性の肺囊胞 を来たしたと推測した。さらにRAの疾患活動性も 上昇していたことより，肺囊胞の原因として BO の 進展，あるいはリウマトイド結節による気管支狭窄 などの可能性も考慮された。このため，入院時より IP に対して methyl-prednisolone $500 \mathrm{mg} /$ 日， 3 日 間のステロイドパルス療法, 後療法として PSL 30 $\mathrm{mg} /$ 日の経口投与を行ったところ, 関節炎は軽快 a

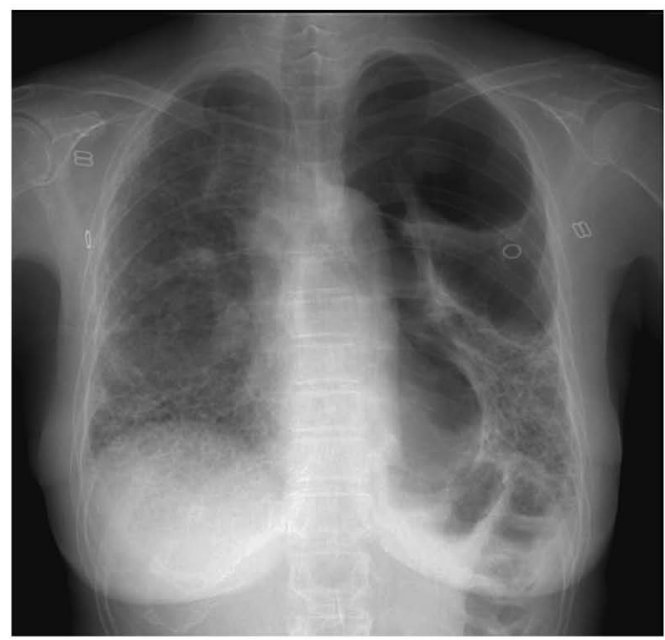

b

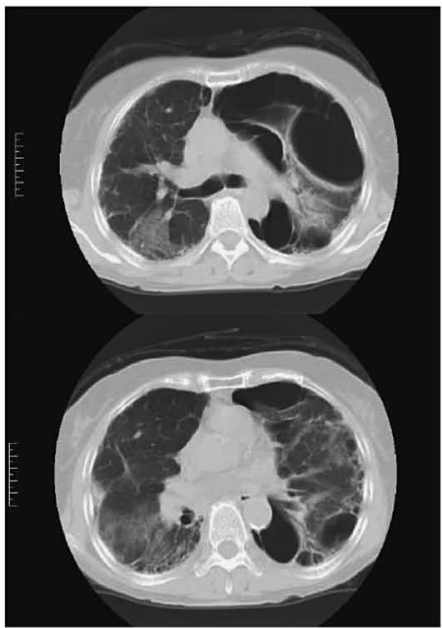

図 1 入院時胸部 $\mathrm{X}$ 線・ $\mathrm{CT}$ 像. a. 胸部 X 線像. 両側に多発性の巨大肺囊胞を認める. b. 胸部 $\mathrm{CT}$ 像. 中〜下肺野で間質性肺炎 の増悪を認める.

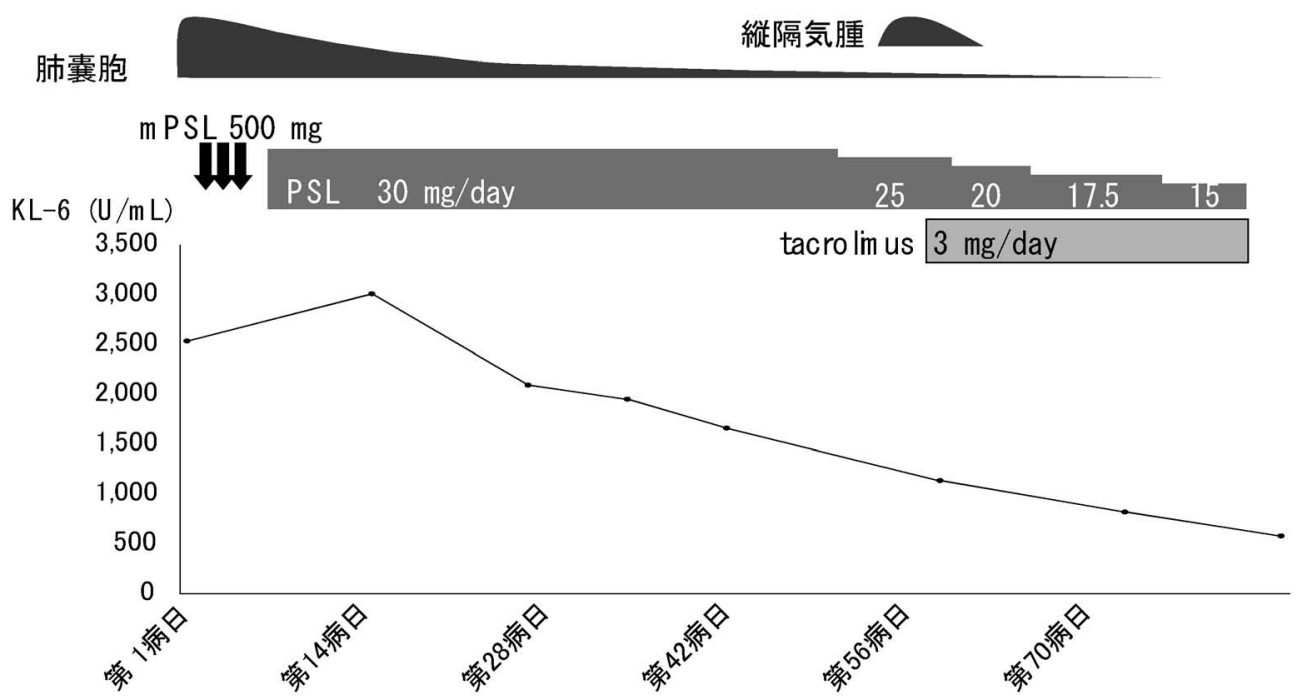

図 2 入院後経過

mPSL : methyl-prednisolone 
し，腫脹関節数，圧痛関節数共に 0 となった. 同時 に肺囊胞の縮小，呼吸困難の改善をみた．画像上の 間質影も改善傾向にあったが，第 55 病日に突然前 胸部の絞扼感の訴えがあり, 胸部 X 線像にて縦隔 気腫の出現を認めた（図 3). 血清 KL-6 值は低下 傾向にあったものの，1,660 U/mL と依然高值であ り，IP の活動性は十分にコントロールされていな いことが推測されたが，副腎皮質ステロイド薬は縦 隔気腫の増悪因子になることから RA に対して高い 有効性が期待できる tacrolimus $2.5-3 \mathrm{mg} /$ 日投与を 開始し，トラフ值を 5-6 ng $/ \mathrm{mL}$ に調整した。その
結果，第 70 病日（治療開始第 15 日目）の胸部 X 線及び CT 像（図 4）では縦隔気腫, スリガラス影 共に著明に改善しており, $\mathrm{PaO}_{2}$ も room air で 80 Torr まで改善した. PSLを $15 \mathrm{mg} /$ 日まで漸減して 第 87 病日に退院となった。経過中, 軽度の手指振 戦以外には有害事象は認められなかった。

\section{III. 考察}

本症例は IP 先行の RA 症例であり, RA の経過 中に IP の増悪と共に多発肺囊胞を発症し, さらに 加療中に縱隔気腫を合併した. 多発肺囊胞の原因と a

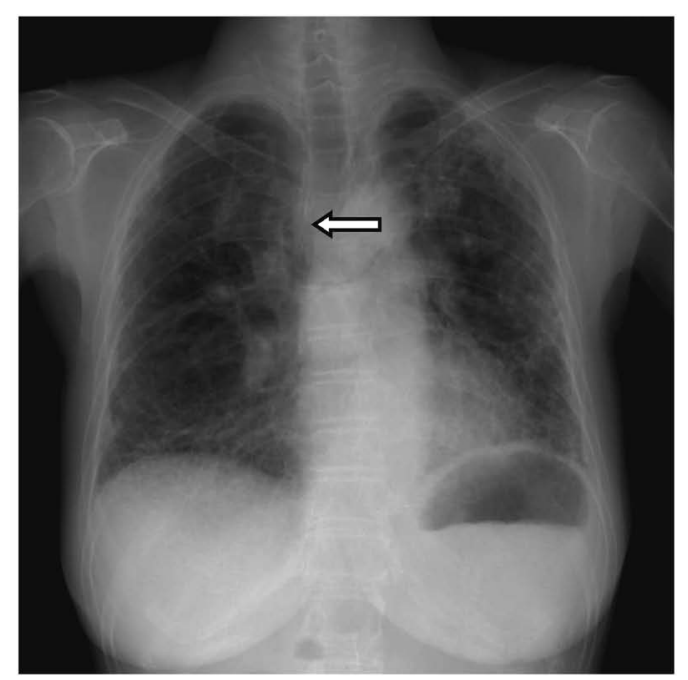

b

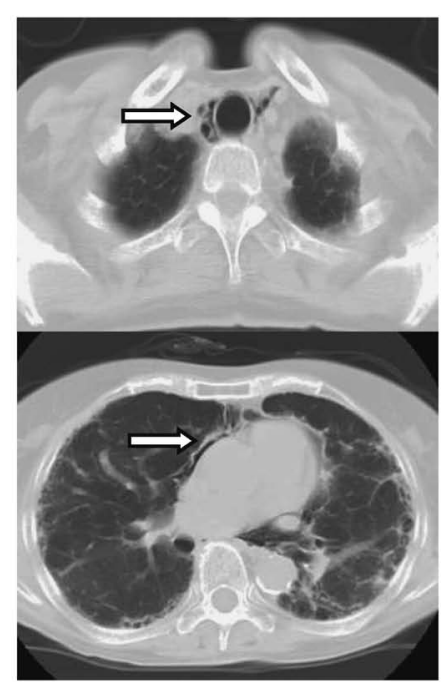

図 3 第 55 病日胸部 X 線. CT 像. a. 胸部 X 線像. b. 胸部 CT 像. 入院時に比べて間質性肺炎像抢よび肺囊胞は改善している. 気管, 気管支, 大動脈の周囲に縦隔気腫を認める (矢印).

a

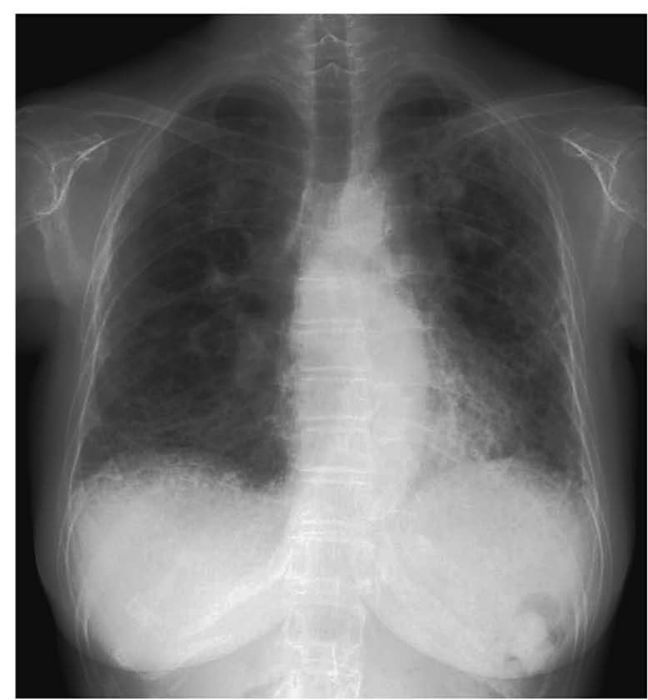

b

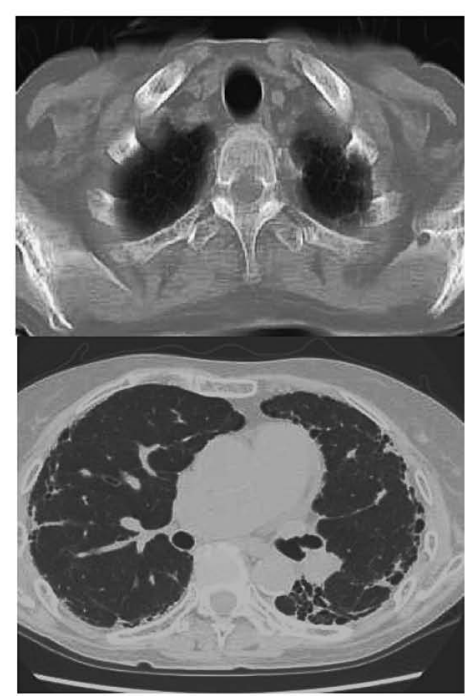

図 4 第 87 病日胸部 $\mathrm{X}$ 線・ CT 像. a. 胸部 X 線像. b. 胸部 CT 像. 図 3 でみられた間質性肺炎像抢よび縦隔気腫共に軽快してい る. 
しては $\mathrm{BO}^{10)}$ ，細菌・ニューモシスチス・抗酸菌な ぞの感染症 ${ }^{11-13)}$, リウマトイド結節 ${ }^{14)}$, シェーグレ ン症候群15)，サルコイドーシス16)などがあり，いず れも細気管支病変による気道閉塞の結果, チェック バルブ機構が働くと考えられている．本症例では囊 胞の壁は薄く，造影効果もなく，また囊胞内貯留物 も認めなかったことより感染は否定的であった。 ま た，RAの疾患活動性の上昇と共に発症したこと, 同時にスリガラス影の拡大や血清 KL-6 值の上昇な ぞ IP の増悪を示唆する所見もみられたこと，さら に副腎皮質ステロイド薬が有効であったことなどよ り，RA に伴う IP に BO 様の病態あるいはリウマ トイド結節を合併して肺震胞が形成された可能性が 高いと考えた。

レイノー現象があり，低力価ながら強皮症を疑わ せるような自己抗体も存在したため，当初は IP の 原因疾患として強皮症を疑ったが，その後の経過中 にも皮膚硬化は認めなかった。また強皮症による IP であれば肺の繊維化による拘束性障害が主な病 態となるが，今回の主病変は細気管支病变で，関節 炎にともなって悪化していたことなどからも，基礎 疾患は強皮症ではなく，RAであると考えられた。

一方，縦隔気腫はしばしば自己免疫性のIP にみ られる難治性の合併症であるが，特にDMにおけ る報告が多い17)。しかし， RA に縦隔気腫が合併し たという症例は我々が調べた限りでは 1 例のみであ り 18)，かなり稀な病態と考えられる．IP に伴う繸 隔気腫の発症機構としては，1）間質の炎症による 肺血管周囲の組織の脆弱化，2）肺血管炎による微 小梗塞や組織壊死，3）副腎皮質ステロイド薬によ る組織脆弱性，などの要因に気道内圧の上昇が加わ り, 縦隔側の肺胞の破壞によって吸気が縦隔に漏出 すると考えられている17). 本症例においても，活動 性の高い IP に副腎皮質ステロイド薬による組織脆 弱性が加わって縦隔気腫を生じたものと考えられ， IP の治療及び副腎皮質ステロイド薬の減量のため に免疫抑制薬の併用が必要であった。さらに，同時 に RAの疾患活動性の上昇がみられたため，RAに 対する有効性が確立している tacrolimus を選択し たところ ${ }^{3)}$ ，IP 及び関節炎のコントロールが可能と なり，同時に副腎皮質ステロイド薬を減量すること ができた.

Tacrolimus はマクロライド系の免疫抑制薬であ り，生体内では FK506 結合性蛋白質と結合する. この複合体が IL-2 などの炎症性サイトカインの発
現に必要な転写因子 NFAT の calcineurin による脱 リン酸化を阻害することで, $\mathrm{T}$ 細胞機能が抑制され る ${ }^{19)}$ 。作用機序は ciclosporin と同様であるが，そ の効果は in vitroに打いて約 100 倍といわれ20)，ま た蔵器移植症例では ciclosporin に比べて副作用が 少ないことも報告されている21)，膠原病および膠原 病類縁疾患の治療抵抗性の病態に打ける tacrolimus の効果については,これまでに PM/DM における 筋炎 ${ }^{7,22)}$, ベーチェット病抢よび顕微鏡的血管炎に 抢けるぶどう膜炎23)，ループス腎炎8などに扔いて 有効性が報告されている.さらに肺病変に対し, 抗 aminoacyl-tRNA 合成酵素抗体陽性の IP 症例 13 例 [PM 6 例, DM 6 例, unclassified connective tissue disease（UCTD） 1 例]に tacrolimus を投与し全例 で改善を認めたという報告5)をはじめ, ciclosporin, cyclophosphamide 抵抗性の $\mathrm{PM} / \mathrm{DM}^{6}$ ) やオーバー ラップ症候群に合併した進行性 IP ${ }^{24)}$ ，ベーチェッ 卜病の肺血管炎 ${ }^{25)}$ に扔いても tacrolimus 投与によ り良好な予後を得た例が報告されている。なかで も，最近 Takada ら ${ }^{4}$ は PM あるいは DMに合併し， ciclosporin 扮よびその他の免疫抑制剂に抵抗性を示 したIPに対し，副腎皮質ステロイド薬との併用下 において tacrolimus がきわめて高い有効性を発揮 することを報告している。このほか，膠原病以外の 疾患に扮いては心肺移植後の ciclosporin 抵抗性の BO に対して有効であったという報告などがある21).

一方，RA 症例に対する tacrolimus の市販後調查 においては, IP が増悪した 15 症例（2006 年 12 月 現在）が報告されており，うち4 例が死亡してい る.このためごく最近になって, RA では tacrolimus の重大な副作用の項目に IP の増悪を追記し, RA にIP を合併している患者を tacrolimus の慎重 投与の項目に入れるという添付文書の改訂がなされ た（http : //med2.astellas.jp/med $/ \mathrm{jp} /)$. このよう な IP の増悪の原因としては，1）RA に基づく IP の急性増悪を tacrolimus 単独ではコントロールで きない，2）tacrolimus 自体が薬剤性 IP を誘発する， 3） tacrolimus 投与によって日和見感染症が誘発さ れる, などの可能性が考えられるが, 現時点では不 明の点が多く今後の検討を要する. しかし我々の経 験では，PM/DM に合併するIP に対して tacrolimus が有効性を発揮する場合には十分量の副腎皮 質ステロイド薬との併用が必要であったこと年，さ らに本症例に打いても tacrolimus は PSL $15 \mathrm{mg} /$ day 以上の副腎皮質ステロイド薬と併用されていた 
ことなどを考慮すると, tacrolimus と副腎皮質ステ ロイド薬との併用療法が IP に対して有効であった 可能性が推測される.

いずれにせよ，本症例は RA に合併する IP に対 しても副腎皮質ステロイド薬との併用下で tacrolimus が有効であることを示唆する症例であり，今 後 RA に合併するIP の治療法を検討する上で貴重 な 1 例であると考え報告した。

\section{文献}

1）駒野有希子，ほか：関節リウマチによる肺病 変とその治療。リウマチ科 $37: 319-325$, 2007.

2) Hakala, M. : Poor prognosis in patients with rheumatoid arthritis hospitalized for interstitial lung fibrosis. Chest 93 : 114-118, 1988.

3) McCarey, D. W., et al. : Tacrolimus therapy in rheumatoid arthritis. Rheumatol (Oxford). 43 : 946-948, 2004.

4) Takada, K., et al. : Polymyositis/dermatomyositis and interstitial lung disease: A new therapeutic approach with T-cell-specific immunosuppressants. Autoimmunity 38:383-392, 2005.

5) Margaret, R., et al. : Treatment of antisynthetase-associated interstitial lung disease with tacrolimus. Arthritis Rheum. 52 : 2439-2446, 2005.

6) Ochi, S., et al.: Favorable outcomes with tacrolimus in two patients with refractory interstitial lung disease associated with polymyositis /dermatomyositis. Clin. Exp. Rheumatol. 23 : 707-710, 2005.

7) Shimojima, Y., et al. : Efficacy of tacrolimus in treatment of polymyositis associated with myasthenia gravis. Clin. Rheumatol. $34: 262-265$, 2004.

8) Mok, C. C., et al. : Tacrolimus for induction therapy of diffuse proliferative lupus nephritis : an open-labeled pilot study. Kidney Int. 68 : 813-817, 2005.

9) Morton, S. J., et al. : Cyclosporin and tacrolimus : their use in a routine clinical setting for scleroderma. Rheumatology 39:865-869, 2000.

10) Suzuki, T., et al. : Bilateral pneumothoraces with multiple bullae in a patient with asymptomatic bronchiolitis obliterans 10 years after bone marrow transplantation. Bone Marrow
Transplant. 23 : 829-831, 1999.

11）金木利通，ほか：糖尿病に合併した感染性多 発性肺囊胞の 1 例. 日胸疾会誌 $35: 801-806$, 1997.

12）松田知之, ほか: 後天性免疫不全症候群に関 連なくカリ二肺炎を契機に多発性肺囊胞を急 激に形成した一例。日呼吸会誌 $39: 508-513$, 2001.

13）井上祐一, ほか: 気腫性囊胞に感染し, 透視 下肺吸引生検にて診断した Mycobacterium szulgai 感染症の 1 例. 感染症学雑誌 72 : 1236-1241, 1998.

14) Taruya, K., et al. : Multiple rheumatoid nodules with rapid thin-walled cavity formation producing pneumothorax. J. Thorac. Imaging $20: 47-49,2005$.

15）照内聡美，ほか：多発性肺囊胞と結節性肺了 ミロイドーシスを伴った Sjögren 症候群の 1 例. 日呼吸会誌 $38: 918-922,2000$.

16）西野聡, ほか: 多発性気腫性囊胞を形成 し, 自然気胸を繰り返したサルコイドーシス の 1 例. 日胸 $\mathbf{5 0}: 591-596,1991$.

17）木野祐子, ほか：皮膚筋炎に縦隔気腫を合併 した 2 例. Clin. Rheumatol. $14:$ 52-57, 2002.

18) Ansul, P., et al. : Persistent pneumomediastinum in interstitial fibrosis associated with rheumatoid arthritis. Chest 117 : 1809-1813, 2000.

19) Liu, J. : FK506 and cyclosporine, molecular probes for studying intracellular signal transduction. Immnol. Today 14 : 290-295, 1993.

20) Dumont, F. J. : FK506, an immunosuppressant targeting calcineurin function. Curr. Med. Chem. 7 : 731-748, 2000.

21) Cairn, J., et al. : Time-related changes in pulmonary function after conversion to tacrolimus in bronchiolitis obliterans syndrome. J. Heart Lung Transplant. 22 : 50-57, 2003.

22) Mitsuki, T., et al. : Successful treatment with tacrolimus in a case of refractory dermatomyositis. Intern. Med. 44 : 1197-1199, 2005.

23) Sloper, C. M., et al. : Tacrolimus (FK506) in their treatment of posterior uveitis refractory to cyclosporine. Ophthalmology $106: 723-728$, 1999.

24）小川法良, ほか : シクロスポリン A 無効の急 性間質性肺炎にタクロリムスを投与したオー バーラップ症候群の 1 例. 中部リウマチ 32 : 76-77, 2001.

25) Koga, T., et al. : Pulmonary infiltrates recovered by FK506 in a patient with Behçet's disease. Chest 104 : 309-311, 1993. 